\title{
A. F. Budd \\ Diversity and extinction in the Cenozoic history of Caribbean reefs
}

Accepted: 22 August 1999

\begin{abstract}
Occurrences of reef corals are examined at Caribbean fossil localities to determine how biodiversity has changed within the region over the past 50 million years. Analyses of 294 species (66 genera) at 58 fossil localities show that Caribbean generic diversity rose to 44 between 50-22 Ma, ranged from 32-39 between 22$2 \mathrm{Ma}$, and dropped to 25 afterwards. Regional species diversity was high at 40-36 Ma, 28-22 Ma, and 5-2 Ma. Origination rates were elevated throughout each high diversity interval, but extinction was concentrated near the end of each interval. Regional highs of origination and extinction, therefore, differed in timing and duration, causing the observed regional diversity increases during the three remarkably long intervals of turnover. Highs of generic origination decreased in magnitude as immigration from the Mediterranean ceased, but speciation highs increased in association with emergence of the Central American isthmus. Peaks of extinction coincided with regional changes in climate and oceanic circulation.

Maximum species diversities within assemblages increased to 40-60 between 50-36 Ma, and have remained relatively constant ever since. Assemblage compositions differed among localities having similar ages and environments, suggesting that the timing and pattern of turnover varied across the region. Stable diversities but variable compositions within assemblages suggest that dispersal and recruitment influenced the pattern of faunal change during turnover.
\end{abstract}

Key words Cenozoic Caribbean - Reef corals · Biodiversity $\cdot$ Extinction

\footnotetext{
A. F. Budd ( $\square)$

Department of Geoscience, University of Iowa,

Iowa City, IA 52242, USA

e-mail: ann-budd@uiowa.edu

Fax: + 1-319-3351821
}

\section{Introduction}

The fossil record provides a unique and valuable perspective on the maintenance of biological diversity on a scale of thousands to millions of years (Sepkoski 1997). On such a large scale, changes in biodiversity result from relative increases in rates of origination and extinction, and changes in faunal composition are irreversible and contingent on previous evolutionary events (see Stanley 1979 for overview). Since the Ordovician, the numbers of genera (and presumably species) of benthic marine organisms remained constant globally during the $\mathrm{Pa}-$ leozoic, and generally increased from the Mesozoic through the Cenozoic (Sepkoski 1997), despite a decrease in the numbers of phyla and orders (Gould 1988). The most significant changes in biodiversity resulted from sharp drops associated with mass extinction. These losses were restored by accelerated speciation during subsequent, more protracted intervals of biotic recovery.

Within marine benthos, reef-building organisms have experienced six primary phases of high diversity through earth history: Early Cambrian, Siluro-Devonian, Permian, Triassic, Cretaceous, and Eocene to Recent (Newell 1971; Copper 1988, 1989). The six phases were each approximately $30-50$ million years in length, and were separated by intervals of low diversity that followed high extinction and lasted as long as 8-20 million years. The extinction episodes corresponded with those in other marine shelf communities and were associated with global climatic cooling and oceanic regression (Sheehan 1985). However, the recovery intervals were unusual in their extended duration, and suggest that reef ecosystems are especially sensitive to large-scale environmental perturbations (Copper 1989).

Within each of the six primary phases, reef communities are interpreted to have been ecologically stable, and to have changed slowly, if at all, by 'in-place' evolution (Sheehan 1996). Most of these minor within-phase changes occurred at low taxonomic levels (i.e., species or genus), and are not well-documented quantitatively. 
Nonetheless, qualitative syntheses have been attempted for reef corals within the sixth primary phase (Eocene to Recent) of the Caribbean region by Vaughan (1919) and Frost (1972, 1977a), and suggest a sequence of five evolutionary units for the region: Middle to Late Eocene, Oligocene to earliest Miocene, Early to Middle Miocene, Late Miocene to Early Pliocene, and Late Pliocene to Recent.

The purpose of the present paper is to provide a revised synthesis of the Cenozoic evolution of scleractinian reef corals in the Caribbean region. As part of the synthesis, I address three sets of interrelated questions:

1. How has taxonomic diversity changed within the Caribbean region over the past 50 million years? Since its initial Eocene rise, has biodiversity remained constant, or has it significantly increased and/or decreased?

2. Have distinct episodes of accelerated origination and/ or extinction occurred within the Caribbean region over the past 50 million years? If so, how do these episodes correspond with reported environmental changes in the Caribbean region? What is the relative timing of peaks of extinction and origination? What impact did they have on regional biodiversity?

3. How have reef communities changed over the past 50 million years? Has turnover been episodic or gradual? Have new species been added to pre-existing communities, and how has extinction affected community structure?

\section{Methods}

Since the earlier syntheses of Vaughan (1919) and Frost (1972, 1977a), many new data have been compiled. Corals have been collected through several Late Cenozoic Caribbean reef sequences using rigorous sampling methods, and age-dates for the sampled horizons have been determined using refined chronostratigraphic methods, integrating the results of biostratigraphic, paleomagnetic, and strontium-isotope analyses. The new collections of corals have been identified using standardized sets of morphologic characters, established in part by comparing morphometric and molecular data, and identifications of previous Cenozoic Caribbean collections have been revised (Budd et al. 1994a; Budd and Johnson 1996, 1999; http://nmita.geology.uiowa.edu). Included among these newly collected sequences are the Mio-Pliocene of the Dominican Republic (Budd et al. 1994b), the Miocene to Early Pleistocene of Curaçao (Budd et al. 1998), and the Late Pliocene to Early Pleistocene of Costa Rica (McNeill et al. 1997; Budd et al. 1999), Jamaica (Budd and McNeill 1998), and the Bahamas (Budd and Johnson 1997; Budd and Kievman 1999).

As a framework for the present synthesis, I have prepared a compilation of all published fossil reef assemblages within the Caribbean region from the Early Eocene (ca. 55 million years ago) until the Late Pleistocene (ca. 150 thousand years ago; Table 1). A faunal list from modern fringing reefs along the north coast of Jamaica (Wells and Lang 1973) was included to represent the composition of the modern Caribbean species pool. The compilation consists of the presence or absence of 294 species (66 genera) in 58 samples - 6 Eocene, 7 Oligocene, 12 Miocene, 19 Pliocene, 13 Pleistocene, 1 Recent. The taxa include all hermatypic species except those belonging to the families Oculinidae and Rhizangiidae. These two families are often represented by species that do not contain zooxanthellae and are therefore not important shallow- water tropical reef builders. Each fossil sample in the compilation is defined as the total assemblage of reef-building coral species recovered from a homogeneous lithologic package of rocks, which has a well-defined geologic age range (usually an established stratigraphic unit such as a Formation or Member). This definition required combining many of the more finely subdivided sampling units in the newly collected sequence (Budd and Johnson 1997, 1999), but was necessary for comparing previously published Eocene and Oligocene assemblages with the newly collected Plio-Pleistocene assemblages. Age ranges in the compilation are still, however, generally longer for geologically older samples.

Any attempt at estimating long-term trends in biodiversity through geologic time is limited by biases in the fossil record, the most notable being taphonomy, transportation and diagenesis (Kidwell and Flessa 1995). Although reef corals are generally wellpreserved in comparison with other marine macroinvertebrates, long continuous reef sequences in the Caribbean fossil record are rare, and evolutionary patterns must be inferred by correlating sequences in different areas. Composite data sets of this nature are especially susceptible to biases created by uneven sampling, inadequate systematics, and imprecise geologic age dates (Budd et al. 1996; Johnson in review). The goal of this initial overview is, therefore, exploratory in nature and broad in scale. Presence-absence data are used in all analyses. Because the data are binary and Caribbean reef environments differ more in relative abundances of species rather than in their presences or absences (Goreau and Wells 1967), separate analyses are not attempted for different reef environments in analyses of community change. In the present analyses, the evolutionary patterns have been assessed using STATPOD (Johnson and McCormick 1998; Johnson in review), and ecological analyses have been performed using PC-ORD multivariate analysis of ecological data (McCune and Mefford 1995). In the ecological analyses, patterns of community change have been assessed using detrended correspondence analyses (DCA), a linear ordination technique in which a total of three ordination axes are computed by reciprocal averaging (McCune and Mefford 1995; Gauch 1982).

\section{The five major Cenozoic faunas}

Middle to Late Eocene (50-33 Ma)

With the possible exception of the Late Paleocene of Alabama (Bryan 1991; Stemann 1997; Stemann and Bryan 1997), the oldest Cenozoic Caribbean reef assemblage containing $>5$ species occurs within the Lower Eocene of Barbados (locality 1) and consists of eight species and seven genera (Table 1). It includes several subsequently important Caribbean reef-building genera (e.g., Astrocoenia, Favia, Goniopora, Montastraea, Siderastrea, and Stylophora), and formed in forereef deposits that were transported into deeper water (Frost 1977a). Older occurrences of the genera $A c$ tinacis, Antillia, Cyathoseris, Haimesastrea, Madracis, Siderastrea, Sideroseris, Stylophora, and Trochoseris are reported in the Paleocene of the US Gulf Coast (Vaughan 1900; Stemann 1997), but are not associated with true coral build-ups (Bryan 1991). Additional isolated occurrences include: Stylophora and Astrocoenia in the Lower Eocene of Jamaica (Wells 1934a), Astreopora in the Paleocene of Belize (Frost 1972, 1977a), and Siderastrea in the Lower Eocene of Chiapas (Frost and Langenheim 1974).

Younger Eocene reef assemblages that are also low in diversity $(<20$ species, $<10$ genera $)$ are reported in the Lower to Middle Eocene of Jamaica (locality 2), the Middle Eocene of St. Bartholomew (locality 3) and of Chiapas (locality 4), and the Upper Eocene of Chiapas (locality 6; Fig. 1, Table 1). Additional Late Eocene assemblages have been described in Cuba (Wells 1934b) and Colombia (Clark and Durham 1946), but are poorly documented and presumably low in diversity. However, significantly increased diversity occurs in shallow forereef deposits of the Middle to Upper Eocene of Panama (locality 5; Budd et al. 1992), which contains 42 species and 22 genera of reef corals (Fig. 1, Table 1) and is roughly equivalent in diversity to the Caribbean today 
Table 1 Locations, stratigraphic units, geologic ages and environments of the 57 analyzed fossil assemblages of Cenozoic Caribbean reef corals. $\mathrm{S}=$ shallow, $\mathrm{I}=$ mid-depth, $\mathrm{D}=$ deep, $\mathrm{F}=$ free-living

\begin{tabular}{|c|c|c|c|c|c|c|c|}
\hline $\begin{array}{l}\text { Locality } \\
\text { No. }\end{array}$ & $\begin{array}{l}\text { Country or } \\
\text { Island }\end{array}$ & Stratigraphic unit & Geologic age & $\begin{array}{l}\text { Youngest } \\
\text { Ma }\end{array}$ & $\begin{array}{l}\text { Oldest } \\
\mathrm{Ma}\end{array}$ & Env & Source \\
\hline 1 & Barbados & Upper Scotland Fm. & E.Eocene & 50.0 & 56 & I & Wells (1945) \\
\hline 2 & Jamaica & Chapelton Fm. & E-M.Eocene & 48.0 & 52 & I & Wells (1934a, 1935) \\
\hline 3 & St. Bartholomew & St. Bartholomew Fm. & M.Eocene & 40.0 & 46 & I & Vaughan (1919) \\
\hline 4 & Mexico & San Juan Fm. & M.Eocene & 40.0 & 46 & SI & Frost and Langenheim (1974) \\
\hline $5^{\mathrm{a}}$ & Panama & Gatuncillo Fm. & M-L.Eocene & 36.0 & 40 & SI & Budd et al. (1992) \\
\hline 6 & Mexico & Ixtaclum Fm. & L.Eocene & 33.0 & 36 & $\mathrm{D}$ & Frost and Langenheim (1974) \\
\hline 7 & Mexico & Rancho Berlin Fm. & E.Oligocene & 28.0 & 32 & $\mathrm{~S}$ & Frost and Langenheim (1974) \\
\hline 8 & Jamaica & Browns Town Fm. & L.Oligocene & 24.0 & 30 & SI & Wallace (1969) \\
\hline 9 & Mexico & La Quinta Fm. & L.Oligocene & 24.0 & 28 & SI & Frost and Langenheim (1974) \\
\hline $10^{\mathrm{a}}$ & Antigua & $\begin{array}{l}\text { Central Plain Grp. } \\
\text { and Antigua Fm. }\end{array}$ & L.Oligocene & 24.0 & 28 & SI & Frost and Weiss (1979) \\
\hline 11 & Texas & Anahuac Fm. & L.Oligocene & 24.0 & 28 & SI & Frost and Schafersman (1978) \\
\hline 12 & $\begin{array}{r}\text { Dominican } \\
\text { Republic }\end{array}$ & Tabera Grp & L.Oligocene & 23.7 & 28.1 & I & Budd et al. (1994b, 1996) \\
\hline $13^{\mathrm{a}}$ & Puerto Rico & $\begin{array}{l}\text { Juana Diaz and } \\
\text { Lares Fms. }\end{array}$ & $\begin{array}{l}\text { L.Olig- } \\
\text { E.Miocene }\end{array}$ & 22.0 & 26 & SID & Frost et al. (1983) \\
\hline 14 & Florida & Tampa Fm. & E.Miocene & 22.0 & 23.7 & $\mathrm{~S}$ & Budd et al. (1994b, 1996) \\
\hline 15 & Panama & Emperador Mem. & E.Miocene & 17.6 & 22 & SI & Budd et al. (1994b, 1996) \\
\hline 16 & Anguilla & Anguilla Fm. & E.Miocene & 16.2 & 22 & SI & Budd et al. $(1989,1995)$ \\
\hline 17 & Mexico & Santa Ana Fm. & E.Miocene & 15.0 & 22 & $\mathrm{~S}$ & Frost and Langenheim (1974) \\
\hline 18 & Florida & Chipola Fm. & E.Miocene & 15.0 & 18 & $\mathrm{~S}$ & Budd et al. (1994b, 1996) \\
\hline 19 & $\begin{array}{r}\text { Dominican } \\
\text { Republic }\end{array}$ & Baitoa Fm. & E.Miocene & 13.1 & 17.3 & $\mathrm{~S}$ & Budd et al. (1994b, 1996) \\
\hline $20^{\mathrm{a}}$ & Curaçao & Seroe Domi Fm. (flatiron) & M.Miocene & 13.1 & 14.1 & $\mathrm{~S}$ & Budd et al. (1998) \\
\hline 21 & Bahamas & Unda-8 & M.Miocene & 11.6 & 11.7 & ID & Budd and Kievman (1999) \\
\hline 22 & Trinidad & Brasso and Tamana Fms. & M.Miocene & 11.5 & 14.8 & ID & Budd et al. (1994b, 1996) \\
\hline $23^{\mathrm{a}}$ & $\begin{array}{r}\text { Dominican } \\
\text { Republic }\end{array}$ & Cercado Fm. & L.Miocene & 7.5 & 8.3 & SIF & Budd et al. (1994b, 1996) \\
\hline 24 & Trinidad & Manzanilla Fm. & L.Miocene & 5.3 & 10.5 & $\mathrm{D}$ & Budd et al. (1994b, 1996) \\
\hline 25 & Curacao & Seroe Domi Fm. (salinaE) & L.Miocene & 5.3 & 8.3 & SI & Budd et al. (1998) \\
\hline 26 & Bahamas & Unda- 6 and 7 & E.Pliocene & 5.2 & 5.4 & ID & Budd and Kievman (1999) \\
\hline 27 & Costa Rica & Río Banano (Brazo Seco) & E.Pliocene & 4.3 & 5.2 & I & Budd et al. (1999) \\
\hline $28^{\mathrm{a}}$ & $\begin{array}{r}\text { Dominican } \\
\text { Republic }\end{array}$ & Gurabo Fm. & $\begin{array}{l}\text { L.Mio- } \\
\text { E.Pliocene }\end{array}$ & 4.0 & 7.5 & IF & Budd et al. (1994b, 1996) \\
\hline $29^{\mathrm{a}}$ & Curaçao & Seroe Domi Fm. (salina) & E.Pliocene & 3.5 & 5.3 & I & Budd et al. (1998) \\
\hline $30^{\mathrm{a}}$ & $\begin{array}{l}\text { Dominican } \\
\text { Republic }\end{array}$ & Mao Fm. & E.Pliocene & 3.4 & 4 & IF & Budd et al. (1994b, 1996) \\
\hline 31 & Costa Rica & $\begin{array}{l}\text { Q. Chocolate Fm. } \\
\text { (Q. Choco. Mem.) }\end{array}$ & L.Pliocene & 3.2 & 3.5 & I & Budd et al. (1999) \\
\hline $32^{\mathrm{a}}$ & Florida & Pinecrest sands & L.Pliocene & 3.0 & 3.5 & $\mathrm{~S}$ & Budd et al. (1994b, 1996) \\
\hline $33^{\mathrm{a}}$ & Costa Rica & $\begin{array}{l}\text { Q. Chocolate Fm. (Buenos } \\
\text { Aires Mem.) }\end{array}$ & L.Pliocene & 2.9 & 3.1 & SI & Budd et al. (1999) \\
\hline $34^{\mathrm{a}}$ & Curacao & Seroe Domi Fm. (ridges) & L.Pliocene & 2.5 & 3.5 & I & Budd et al. (1998) \\
\hline $35^{\mathrm{a}}$ & Jamaica & Bowden Fm. & L.Pliocene & 2.5 & 3.4 & $\mathrm{~F}$ & Budd and McNeill (1998) \\
\hline $36^{\mathrm{a}}$ & Costa Rica & $\begin{array}{l}\text { Moín Fm. (Empalme } \\
\text { and St. Rosa) }\end{array}$ & L.Pliocene & 1.9 & 2.9 & $\mathrm{~S}$ & Budd et al. (1999) \\
\hline $37^{\mathrm{a}}$ & Curaçao & Seroe Domi Fm. (seacliff) & L.Pliocene & 1.8 & 2.5 & SI & Budd et al. (1998) \\
\hline 38 & Curaçao & Highest Terrace & L.Pliocene & 1.8 & 2.5 & I & Budd et al. (1998) \\
\hline $39^{\mathrm{a}}$ & Jamaica & Hope Gate Fm. & L.Pliocene & 1.8 & 2.2 & SI & Budd and McNeill (1998) \\
\hline 40 & Bahamas & Clino-4-6 & L.Pliocene & 1.8 & 2.2 & ID & Budd and Kievman (1999) \\
\hline $41^{\mathrm{a}}$ & Panama & Bocas del Toro & L.Pliocene & 1.7 & 3.5 & IDF & Budd et al. (1999) \\
\hline $42^{\mathrm{a}}$ & Bahamas & Unda-2-5 & L.Pliocene & 1.7 & 2.2 & I & Budd and Kievman (1999) \\
\hline $43^{\mathrm{a}}$ & Jamaica & Old Pera Beds & L.Pliocene & 1.6 & 2.5 & I & Budd and McNeill (1998) \\
\hline 44 & Jamaica & Navy Island Mem. & E.Pleistocene & 1.6 & 1.9 & SI & Budd and McNeill (1998) \\
\hline $45^{\mathrm{a}}$ & Costa Rica & $\begin{array}{l}\text { Moin Fm. (Lomas and } \\
\text { Portete) }\end{array}$ & E.Pleistocene & 1.5 & 1.9 & $\mathrm{D}$ & Budd et al. (1999) \\
\hline 46 & Curaçao & Higher Terrace & E.Pleistocene & 1.4 & 2 & I & Budd et al. (1998) \\
\hline 47 & Bahamas & Clino-2-3 & E.Pleistocene & 1.3 & 1.8 & $\mathrm{~S}$ & Budd and Kievman (1999) \\
\hline $48^{\mathrm{a}}$ & Jamaica & Manchioneal Fm. & E.Pleistocene & 1.1 & 1.6 & SI & Budd and McNeill (1998) \\
\hline 49 & Cuba & $\begin{array}{l}\text { La Cruz and } \\
\text { Matanzas Fms. }\end{array}$ & $\begin{array}{l}\text { L.Plio- } \\
\text { E.Pleistocene }\end{array}$ & 1.0 & 3.5 & SI & Budd et al. (1999) \\
\hline 50 & Florida & $\begin{array}{l}\text { Caloosahatchee and } \\
\text { Glades Fms. }\end{array}$ & E.Pleistocene & 1.0 & 1.8 & $\mathrm{~S}$ & Budd et al. (1994b, 1996) \\
\hline 51 & Bahamas & Unda-1 & M.Pleistocene & 0.5 & 0.7 & $\mathrm{~S}$ & Budd and Kievman (1999) \\
\hline 52 & Bahamas & Clino-1 & M.Pleistocene & 0.2 & 0.9 & $\mathrm{~S}$ & Budd and Kievman (1999) \\
\hline
\end{tabular}


Table 1 (Cont.)

\begin{tabular}{llllllll}
\hline 53 & Curaçao & Middle and Lower Terraces & M-L.Pleistocene & 0.1 & 0.6 & S & Budd et al. (1998) \\
54 & $\begin{array}{l}\text { Dominican } \\
\text { Republic }\end{array}$ & Santo Domingo Terraces & M-L.Pleistocene & 0.1 & 0.5 & S & Budd et al. (1994b, 1996) \\
& & & & & & \\
$55^{\mathrm{a}}$ & San Andrés & San Andrés Terraces & M-L.Pleistocene & 0.1 & 0.5 & S & Budd et al. (1994b, 1996) \\
56 & Florida & Key Largo Fm. & M-L.Pleistocene & 0.1 & 0.5 & S & Budd et al. (1994b, 1996) \\
57 & Jamaica & Falmouth Fm. & L.Pleistocene & 0.1 & 0.2 & S & Budd and McNeill (1998) \\
\hline
\end{tabular}

${ }^{\mathrm{a}}$ Well-sampled

A

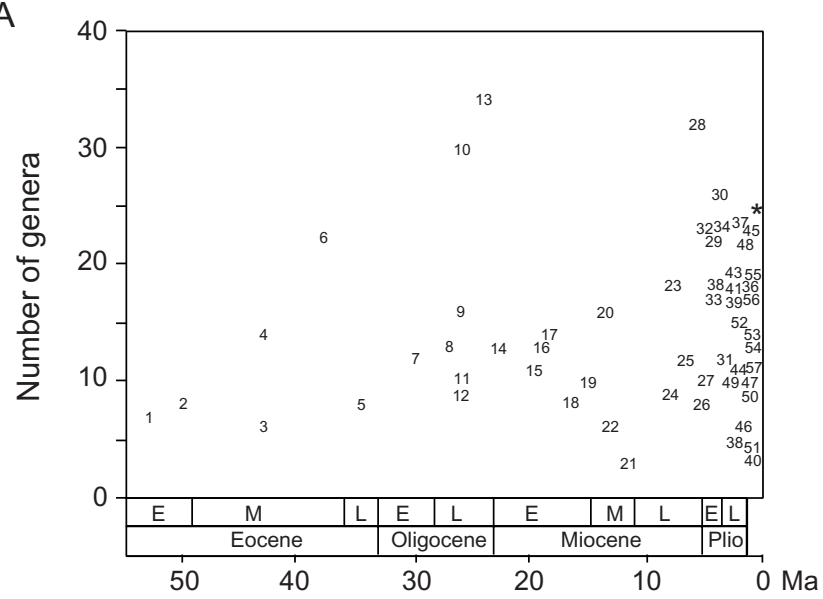

B

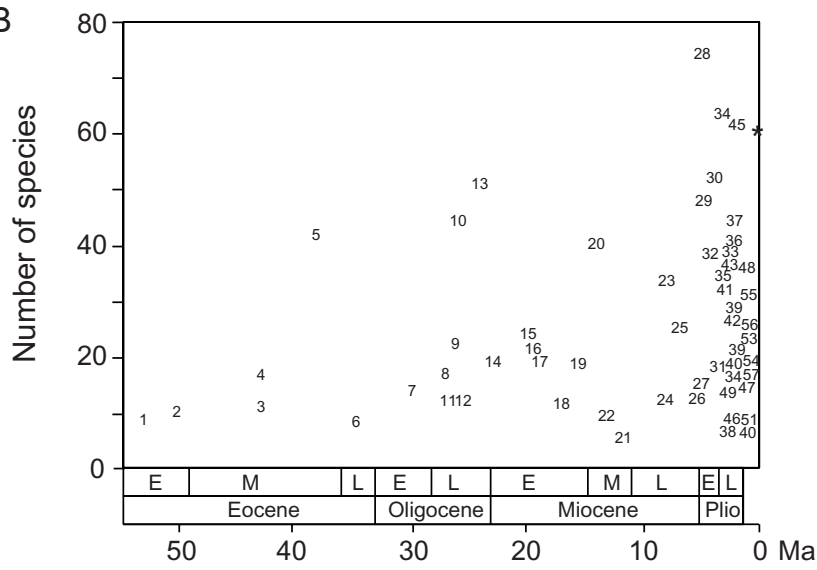

Fig. 1A, B Numbers of taxa recorded within 57 fossil assemblages of Cenozoic Caribbean reef corals. Each point represents an assemblage. The assemblages are marked by locality numbers listed in Table 1 . The geologic age plotted for each assemblage is the midpoint between the oldest and youngest age estimates given in Table 1. A Numbers of genera per assemblage. B Numbers of species per assemblage

(Recent Jamaica $=61$ species, 25 genera). Thus, by Middle to Late Eocene time, the species pool in the Caribbean had established a diversity comparable to the modern species pool.

In sum, a total of 77 species and 36 genera are known from the Caribbean Eocene. Consequently, more than half of the 66 reef coral genera recorded for the entire Caribbean Cenozoic lived in the region during Eocene time (Fig. 2). Of these 36 genera, nine $(25 \%)$ occurred in the Caribbean Cenozoic only during the Eocene, and $11(31 \%)$ continue to live in the region today. The remaining 16 genera had last-occurrences in the region during either the Late Oligocene (six genera), Early to Middle Miocene (five genera), Late Miocene (two genera), or Plio-Pleistocene (three genera). A preliminary review of occurrences of the 36 Eocene genera in older Cretaceous units of the Caribbean and Mediterranean regions
(Wells 1956) and in older or contemporaneous Paleocene and Eocene units of the Mediterranean region (Schuster 1996) suggests that 16 of the 36 genera $(44 \%)$ were common in the Tethyan realm during the Cretaceous, and that 14 of the 20 genera $(70 \%)$ with no pre-Paleogene record also occur in the Mediterranean Paleocene and/or Eocene (Fig. 2). Four of the remaining six genera (Sideroseris, Haimesastrea, Antilloseris, ?Antillia) appear to have been restricted to the Caribbean; the other two (Coscinaraea, Pocillopora) occurred only in the Caribbean and Indo-Pacific. Thus, the 36 Eocene Caribbean genera may have been part of a cosmopolitan fauna that survived the Cretaceous extinction (Rosen and Turnsek 1989) and further diversified across both the Caribbean and Mediterranean regions during Paleocene and Eocene time.

Oligocene to earliest Miocene (33-22 Ma)

Reefs are poorly known in the Caribbean during the Early Oligocene, but are diverse and well-developed during the Late Oligocene. The only reef assemblage reported from the Early Oligocene (Table 1, Fig. 1) occurs in Chiapas, Mexico (locality 7), and is moderately diverse (17 species, 14 genera). In contrast, high diversities comparable to the Eocene of Panama are reported in the well-developed fringing reef systems in the Upper Oligocene of Antigua (locality 10; 44 species, 30 genera: Vaughan 1919; Frost and Weiss 1979) and in the Upper Oligocene to lowermost Miocene of Puerto Rico (locality 13; 51 species, 34 genera; Frost et al. 1983). In these two reef systems, Diploastrea, Antiguastrea, massive Porites, Goniopora, and Astreopora dominated reef crest and shallow forereef deposits; branching Stylophora, Acropora, and Porites dominated mid-forereef deposits; Leptoseris, platy Porites, and Hydnophora dominated deep forereef deposits; and Colpophyllia and Favites were more common in backreef deposits. In protected environments, branching Porites, Montastraea, and Agathiphyllia were most abundant.

A total of 68 species and 37 genera are reported from the Caribbean Oligocene. Given that Dichocoenia, Madracis, and Antillia have Eocene and Miocene but not Oligocene records, approximately two thirds (40 out of 66) of all reef coral genera within the entire Caribbean Cenozoic had Caribbean ranges that extended through Oligocene time (Table 2). Twenty-three of the 37 recorded genera and 11 of the 68 species also occur in the Caribbean Eocene. Of the 14 genera with no Caribbean Eocene record, one (Stephanocoenia) is reported in the Cretaceous, seven in the Mediterranean Paleogene, four in post-Paleogene of both the Caribbean and Indo-Pacific, and two (Mycetophyllia, Diploria) only in the Caribbean. Only 5 of the 14 genera with no Caribbean Eocene record continue to live in the Caribbean today. Thus, the Oligocene represents a highpoint in Caribbean reef coral generic diversity, and a continuation of the 'plateau' of maximum species diversity that was established for the region by the Middle to Late Eocene. In a species-level comparison between Late Oligocene Caribbean and Mediterranean reef corals, Frost (1977b, c; 1981) estimated that $\sim 50 \%$ of Caribbean species had spatial distributions that extended into the Mediterranean. Furthermore, 27 of the $37(73 \%)$ Caribbean genera had distributions that extended into the Mediterranean. Thus, like the Eocene Caribbean fauna, the Oligocene fauna consisted mostly of cosmopolitan taxa whose distributions extended at least across the western portion of the Tethyan realm. 


\section{Cenozoic Caribbean Reef Coral Genera}

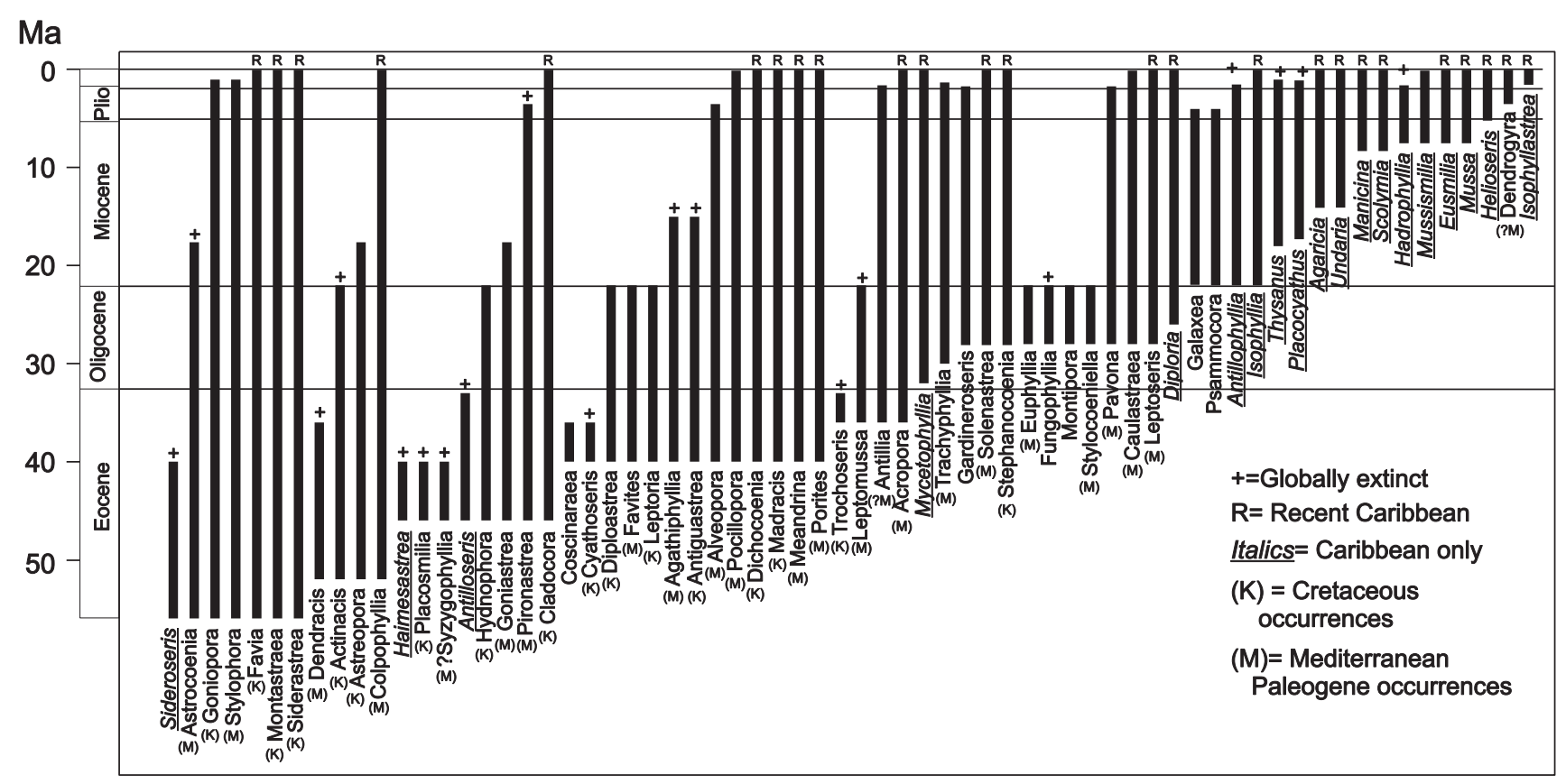

Fig. 2 Ranges of all known reef coral genera (total $=66$ ) within in the Caribbean region during Cenozoic time. The ranges are based on occurrences in the 57 localities listed in Table 1. Ends of range lines are maximum age estimates for localities in which first and last occurrences take place. Taxa are arranged in order of origination

\section{Early to Middle Miocene (22-10 Ma)}

In contrast to the Late Oligocene, reefs were generally small in size and low in diversity during the Early to Middle Miocene (Budd et al. 1989, 1995). Most consisted of $\sim 20$ species within fewer than 15 reef coral genera (Fig. 1, Table 1) and were dominated by species of Montastraea and Porites. Classic examples include shallow to intermediate-depth patch reef deposits within the upper Lower Miocene of Anguilla (locality 16; Budd et al. 1989, 1995), Panama (locality 15) (Vaughan 1919), and Chiapas (locality 17; Frost and Langenheim 1974). By far the most diverse assemblages (40 species, 16 genera), however, occur in younger Middle Miocene deposits of Curaçao (locality 20), and were dominated by massive species of Porites, Goniopora, Montastraea, and Psammocora (Budd et al. 1998).

A total of 80 species and 33 genera are reported from the Caribbean Early to Middle Miocene. Ten of the 40 Oligocene Caribbean genera (including the large framework builders Actinacis, Favites, Leptoria, Hydnophora, Diploastrea) had last-occurrences near the Oligo-Miocene boundary, and 5 of the 30 survivors (Astrocoenia, Astreopora, Goniastrea, Agathiphyllia, Antiguastrea) became extinct in the region during the Early Miocene. Thus, extinction may have generally accelerated during the Late Oligocene and Early Miocene. Four genera (Agaricia, Undaria, Placocyathus, and Thysanus) first occurred during the Early to Middle Miocene, but all had distributions that were restricted to the Caribbean, suggesting that the Caribbean reef coral fauna had lost its cosmopolitan trans-Atlantic character by the Early Miocene and become more provincial. By the Late Miocene, all reef-building corals in the Mediterranean had become extinct (Chevalier 1977), and so no longer influenced evolutionary events within the Caribbean.

\section{Late Miocene to Early Pliocene (10-3.5 Ma)}

The most diverse Caribbean reef coral assemblages throughout Cenozoic time are Late Miocene to Early Pliocene in age (Fig. 1).
Classic examples include shallow to deep patch reefs and coral-rich grass flats of the northern Dominican Republic (localities 23, 28, 30; Saunders et al. 1986; Evans 1986; Budd et al. 1994b, 1996). Other examples (Table 1) include shallow to intermediate-depth siliciclastics in Curaçao (locality 25, 29), and deep reef deposits in Trinidad (locality 24). Carbonate sequences containing well-developed barrier reef systems were rare in the Caribbean during the Late Miocene to Early Pliocene; however, one poorly preserved reef sequence occurs on Isla de Mona, Puerto Rico (González et al. 1997), and consists of 19 species and 13 genera.

A total of 114 species and 39 genera are reported from the Caribbean Late Miocene to Early Pliocene. Given that Cladocora is unrecorded but its range extends through the Mio-Pliocene, a total of 40 genera may have lived in the Caribbean though this time interval. Eight genera have first occurrences during the Mio-Pliocene, and all except Scolymia have geographic distributions restricted to the Caribbean. Only two genera have first occurrences during the Late Pliocene to the Recent; therefore, the increased generic origination during the Mio-Pliocene represents the youngest peak of origination during the Cenozoic. Of the eight new genera, two (Manicina, Hadrophyllia) were primarily free-living and preferred grass flat and soft substrate environments, and four (Scolymia, Mussa, Helioseris, Eusmilia) were more abundant in turbid or deep reef environments. Twenty-three of the 40 MioPliocene genera live today in the Caribbean. Four of the 17 genera that became extinct in the Caribbean had last occurrences during the Early Pliocene; 12 of the remaining 13 genera that became extinct in the Caribbean had last occurrences during the PlioPleistocene. Of the four genera that became extinct during the Early Pliocene, three (Alveopora, Galaxea, and Psammocora) live today in the Indo-Pacific region. In general, the maximum species diversity of the Mio-Pliocene assemblages was higher than the assemblages of either the Late Oligocene or Recent (Fig. 1); however, their generic diversity was equivalent to those of the Late Oligocene but higher than the Recent.

\section{Late Pliocene to Recent (3.5-0 Ma)}

The Late Pliocene to Recent fauna is the most intensely sampled of the five Cenozoic Caribbean faunas, in part because of increased collecting efforts over the past 5 years in Costa Rica, Jamaica, and 
Curaçao, and collaborative analyses of the Bahamas Drilling project cores (Budd and Johnson 1999). A total of 27 Late Pliocene and Pleistocene samples in a wide range of reef environments (Table 1) are included in the compilation, the most diverse being in Curaçao (Budd et al. 1998) and Costa Rica (Budd et al. 1999).

A total of 133 species and 38 genera are reported in the Caribbean Plio-Pleistocene. As explained above, all but two of the 38 genera originated before the Late Pliocene, and 13 of the 38 genera and 77 of the 133 species are currently extinct in the region. All but one species (Pocillopora palmata) in the compilation were extinct by the Middle Pleistocene, indicating that a major episode of extinction occurred during the latest Pliocene and Early Pleistocene. As described by Budd et al. (1994b), 7 of the 13 genera that became extinct currently occur in the Indo-Pacific, and two (Pavona, Pocillopora) are now dominant constituents of modern Eastern Pacific reefs. Recent Caribbean reefs (61 species, 25 genera) are thus low in diversity in comparison to their Plio-Pleistocene counterparts.

\section{Results}

Biodiversity, origination and extinction patterns through geologic time

Patterns of change were examined in the entire Caribbean reef coral fauna over the past 50 million years by subdividing the compilation into 1 million year intervals, and counting numbers of genera and species within each time interval. The results (Fig. 3) show that total numbers of genera in the region gradually increased from Early Eocene to Oligo-Miocene time (50-22 Ma). After a minor drop in the Early Miocene, numbers of genera remained fairly constant until Plio-Pleistocene time (2$1 \mathrm{Ma}$ ), when they decreased to current levels. The general pattern is similar to that observed in maximum numbers of genera per assemblage (Fig. 1A). In con- trast, total numbers of species in the region experienced small peaks in the Middle to Late Eocene (40-36 Ma) and in the Late Oligocene to earliest Miocene (28$22 \mathrm{Ma}$ ), and a large peak during the Early Pliocene (5$2 \mathrm{Ma}$; Fig. 3). Despite these peaks, maximum numbers of species per assemblage appear to level off between 40 60 species by the Middle to Late Eocene (50-40 Ma) and to remain constant through the remainder of the Cenozoic. A possible exception occurs during Mio-Pliocene time when $>70$ species have been recorded in one locality (Fig. 1B).

Evolutionary rates were calculated by counting numbers of first and last occurrences of taxa within each 1 million year time interval and dividing by the total number of taxa recorded in the interval (see Budd et al. 1996 for details). The results (Fig. 4) reveal that rates of generic and species origination were high during: (1) the Middle to Late Eocene (40-36 Ma), (2) the Late Oligocene to earliest Miocene (28-24 Ma), and (3) the Late Miocene to Early Pliocene (7-4 Ma). An additional peak in species origination occurred during the Middle Miocene (14-12 Ma). All of the observed highs are poorly defined and low in intensity, and they extend over broad time intervals, frequently lasting more than 5 million years. In particular, high rates of species origination prevailed generally across the region from the Middle Eocene to Late Oligocene (46-24 Ma). Furthermore, the peaks of generic origination decreased in size through time, but peaks of species origination were roughly equal in intensity.

Similarly, high rates of generic and species extinction occurred over broad intervals in the Middle to Late Eocene (46-36 Ma) and the Late Oligocene to earliest
Fig. 3A, B Estimated numbers of taxa living in the entire Caribbean region over the past 50 million years. The data consist of faunal lists for the 57 localities listed in Table 1. The estimates were made using 1-million-year intervals. A Genus richness. B Species richness

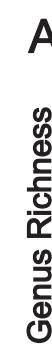

B
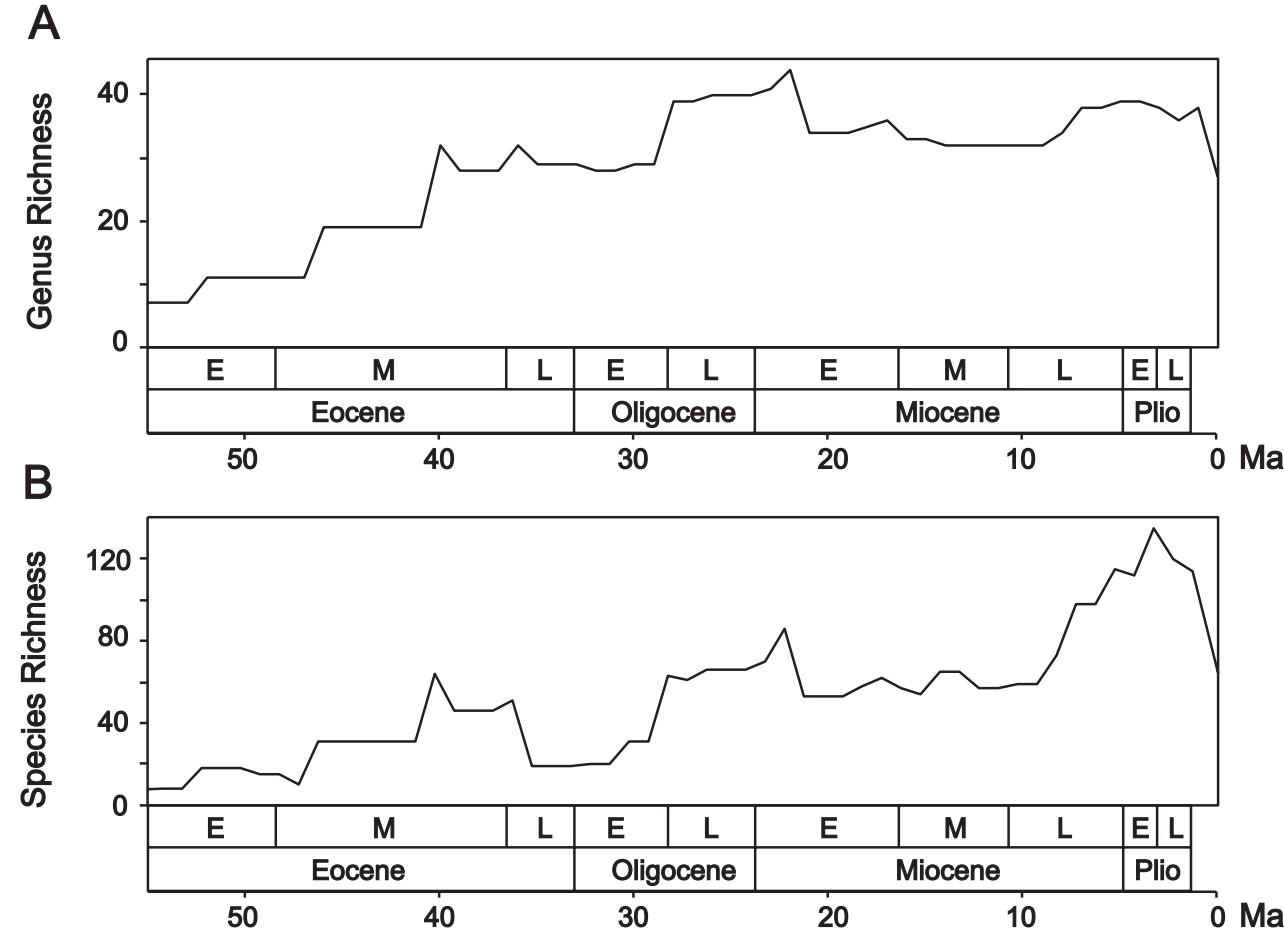
Fig. 4A, B Evolutionary rates of Caribbean reef corals over the past 50 million years, based on faunal lists for the 57 localities listed in Table 1. The estimates were made using 1million-year intervals, and occurrences within each interval were weighted relative to the duration of the locality in which they occurred. Extinction rates are indicated by solid lines; origination rates are indicated by dotted lines. A Genus rates. B Species rates
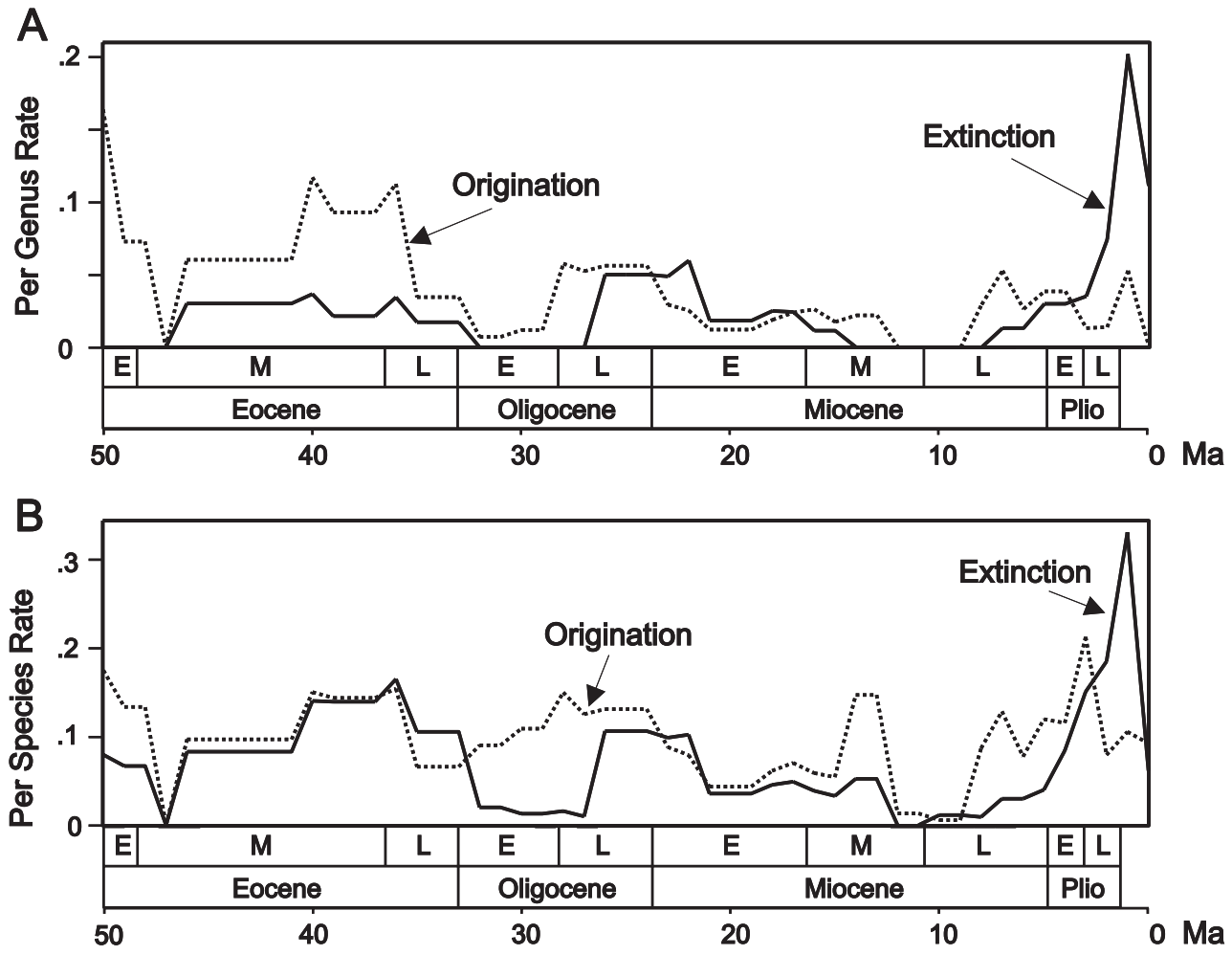

Miocene (26-22 Ma). Distinct, well-developed peaks of extinction took place in both genera and species during the Plio-Pleistocene (2-1 Ma). In each case, the PlioPleistocene peak exceeded all other Cenozoic peaks in intensity and was notably shorter in duration.

In general, the Caribbean reef coral fauna experienced accelerated rates of turnover in association with three broad Cenozoic highs in species diversity. At the time of these apparent highs, more localities are reported in the fossil record and more samples are represented in the compilation. Therefore, the intensity and duration of the observed peaks may be affected by sampling and require further scrutiny and evaluation using statistical resampling techniques (Johnson in review). Visual comparisons of timing between extinction and origination events indicate that increased origination preceded increased extinction in the region during both the Late Oligocene (28-22 Ma) and Pliocene (5-2 Ma) intervals of accelerated turnover. This apparent asynchroneity in evolutionary events may have been responsible for the observed protracted intervals of accelerated faunal change, which increased the overall species richness of the region.

Constancy and patterns of change within the fauna

The substantial variation in regional species diversity (Fig. 3), despite the constancy in species diversity within assemblages (Fig. 1) over the past 50 million years suggests that patterns of change within local reef communities during regional turnover may have been partially constrained. As a preliminary first step in understanding these constraints, I performed detrended correspondence analyses (DCA) using presence-absence data for species in well-sampled (containing $>25$ species) assemblages listed in Table 1. The results (Fig. 5A) suggest that Eocene (A), Oligocene (B), and Miocene to Recent (C, D, E, F) assemblages are distinct. However, because of lack of adequate samples during 5-10 million years of time between these three major faunal groups, no conclusions can be made about the gradual vs. episodic nature of the transitions between major faunas. Within the Miocene to Recent group, Middle Miocene (C), Mio-Pliocene (D), and Pleistocene to Recent (F, R) assemblages also appear to be distinct; however, Plio-Pleistocene (E) assemblages form a continuum extending between Mio-Pliocene and Pleistocene-Recent faunal types. The continuum does not appear to be correlated with ages of the assemblages, but is more closely linked to the proportion of extant species within each assemblage. Interestingly, Mio-Pliocene assemblages in the analysis form a tight group and are very similar, even though they span a longer time interval (8-4 Ma) than the PlioPleistocene continuum (3.5-1.5 Ma). This result suggests that a period of relative faunal constancy may have preceded Plio-Pleistocene faunal change.

Detrended correspondence analysis of well-sampled assemblages over the past 10 million years (Fig. 5B) further indicates that, even though reef communities were diverse and plentiful across the Caribbean during the transition from Mio-Pliocene to Pleistocene-Recent faunas, the transition was neither simple nor orderly. Change of species composition in protected reef environments (localities 35, 42, 43) lagged behind change in 

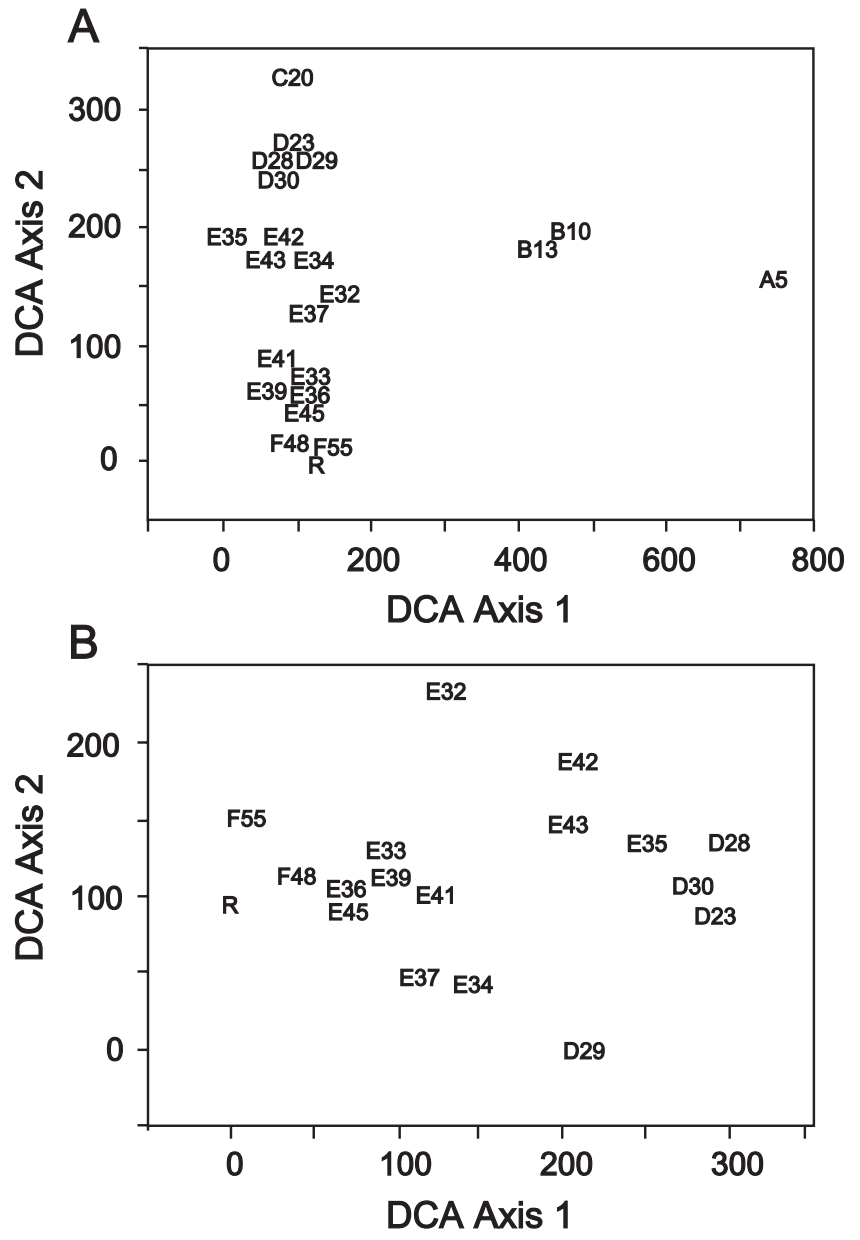

Fig. 5A, B Detrended correspondence analysis (DCA) of assemblages containing $>25$ species (Table 1). The data set consisted of presences and absences of species reported in each assemblage. Each point on the plot represents an assemblage. The assemblages are marked by locality numbers listed in Table 1, and are prefaced with: $A$ Middle to Late Eocene, $B$ Oligocene to earliest Miocene, $C$ Early to Middle Miocene, $D$ Late Miocene to Early Pliocene, $E$ Late Pliocene to Early Pleistocene, $F$ Middle to Late Pleistocene, $R$ Recent. A DCA analysis of 22 assemblages over the past 50 million years. B DCA analysis of 18 assemblages over the past 10 million years

more exposed environments (localities 33, 36, 39; Budd and Johnson 1997, 1999; Budd and McNeill 1998). Furthermore, turnover may have proceeded more rapidly at northern locations (locality 32 ).

\section{Discussion and conclusions}

Clearly both biotic and abiotic factors have influenced the evolutionary history of Caribbean reefs. The increases in regional species diversity associated with the three main intervals of turnover (Middle to Late Eocene, Late Oligocene to Early Miocene, and Pliocene to Pleistocene) and the variable composition of communities and variable timing of evolutionary events during Plio-Pleistocene turnover suggest that the compositions of Caribbean reef communities were not limited to a fixed set of species (Aronson and Precht 1997); however, constant maximum numbers of species within assemblages (Fig. 1B) suggest that the total number of species at any one location may have been limited. Furthermore, regional generic diversity (Fig. 3B) and its recovery following losses in response to environmental perturbations appear to have been strongly correlated with the areal extent of the dispersal pool and spacing between populations (Rosen 1984). Thus, many of the most important controls on Caribbean reef diversity appear to be associated with biotic factors related to biogeography, such as dispersal.

Indeed, numbers of genera increased in the Caribbean region from Early Eocene to Late Oligocene time (50$22 \mathrm{Ma}$ ), until dispersal across the Atlantic from the Mediterranean ceased (Frost 1977b). In fact, 53 of the 66 genera that lived in the Caribbean during the Cenozoic first-occurred in the region before the earliest Miocene $(\sim 22 \mathrm{Ma})$. Genera that first occurred in the region after the earliest Miocene had distributions limited to the Caribbean region, and prevailed in marginal deep reef or seagrass environments. Most originated during the 5 million year interval preceding the final closure of the Central American isthmus (at $3.5 \mathrm{Ma}$ ), as circulation patterns changed within the Caribbean region (Coates et al. 1992; Jackson and Budd 1996; Collins et al. 1996). Furthermore, peaks of generic extinction were not significant in the region until after the Late Oligocene. The most intense peak in generic extinction occurred during the Plio-Pleistocene, as climates deteriorated in response to the onset of northern hemisphere glaciation. The effects of these environmental perturbations may have been more intense because they occurred at a time when the size of the dispersal pool was at an all-time low due to the recent emergence of the Central American isthmus.

The three main species extinction highs (Middle to Late Eocene, Late Oligocene to Early Miocene, and Plio-Pleistocene) each coincided with large-scale environmental perturbations. Global drops in temperature have been widely cited as the cause of Middle to Late Eocene extinctions in both terrestrial and marine biotas (Prothero 1994). Increased upwelling and associated turbidity and cooling have been inferred for the Caribbean during the Early Miocene (Edinger and Risk 1994, 1995). Drops in sea surface temperature associated with the onset of northern hemisphere glaciation affected many different marine organisms (including molluscs and bryozoans) in the Caribbean during the Late Pliocene (Stanley 1986; Jackson et al. 1993, 1996; Jackson and Budd 1996). Studies of extinction selectivity (Edinger and Risk 1994, 1995) indicate that cold-tolerant, eurytopic reef coral species that brood larvae were more likely to survive extinction during the Late Oligocene to Early Miocene; whereas reef coral species with large maximum colony sizes and longer generation times were more likely to survive extinction during the Plio-Pleistocene (Johnson et al. 1995). The two earlier extinction highs (Middle to Late Eocene, Late Oligocene to Early Miocene) extended over periods of approximately 
5 million years and were therefore less intense than the Plio-Pleistocene extinction peak, which lasted for a million years or less. After each of the two earlier extinctions, species richness took 5-10 million years to recover across the Caribbean region, and it has not yet fully recovered from Plio-Pleistocene extinction.

Given the many unexplored sample biases and inadequacies in currently available data, the history of biodiversity on Caribbean reefs can be tentatively summarized as follows:

1. Numbers of Caribbean reef coral genera increased both locally and regionally from the Early Eocene to the Late Oligocene (50-22 Ma), and then leveled off at between 30-40 genera until the Late Pliocene (22-2 Ma). During the Plio-Pleistocene (2-1 Ma), numbers of genera in the region dropped to the 25 that live in the Caribbean today. Generic diversity in the region and its recovery from losses caused by environmental perturbations appear to be related to biogeographic factors (e.g., size of the dispersal pool) and thus may have been controlled by the size and structure of metapopulations.

2. Total numbers of Caribbean reef coral species experienced three broad highs [Middle to Late Eocene (40$36 \mathrm{Ma})$, Late Oligocene to earliest Miocene (28-22 Ma), Late Miocene to Late Pliocene (5-2 Ma)], corresponding with periods of maximal reef development. Maximum numbers of species per assemblage increased from Early to Late Eocene (50-40 Ma), and appear to have leveled off to between 40-60 species through the rest of the Cenozoic (40-0 Ma). Given the variable composition observed in reef assemblages, the apparent ceiling in numbers of species per assemblage within any one environment may be related to dispersal and recruitment.

3. Rates of genus origination were high in the Caribbean during the Middle to Late Eocene (40-36 Ma) and during the Late Oligocene to earliest Miocene (28$24 \mathrm{Ma}$ ), and to a lesser extent during the Late Miocene to Early Pliocene (7-4 Ma). The general decrease in rates of genus origination through the Cenozoic is correlated with the cessation of dispersal from the Mediterranean region. Rates of species origination were high during the Middle Eocene to earliest Miocene (46$24 \mathrm{Ma}$ ), the Middle Miocene (14-12 Ma), and the Late Miocene to Early Pliocene (7-3 Ma). High origination rates during the Late Miocene to Early Pliocene involved species that prevailed in marginal deep reef or seagrass environments, and appear to be associated with increased environmental heterogeneity (especially carbonate-rich environments) preceding the emergence of the Central American isthmus (Collins et al. 1996).

4. Rates of genus and species extinction were high during a 4 million year interval in the Late Oligocene to earliest Miocene (26-22 Ma) and during the Plio-Pleistocene $(2-1 \mathrm{Ma})$. Species extinction rates were also high during a broad interval in the Middle to Late Eocene (46-36 Ma). These highs coincided with changes in climate (Eocene, Plio-Pleistocene) and upwelling (Oligo-Miocene). The intensity of extinction was highest by far during the Plio-Pleistocene.
5. Peaks of origination and extinction do not appear to have been synchronous for either genera or species, and as a consequence, numbers of species in the species pool increased during protracted periods of accelerated faunal change. Intervals of turnover were, therefore, not regionally episodic, and may have lasted up to 5 million years. With the possible exception of the Plio-Pleistocene, high turnover rates had little effect on the numbers of genera living in the Caribbean region or on maximum numbers of species per assemblage.

6. Middle to Late Eocene, Late Oligocene, and Middle Miocene-Recent assemblages were distinct in composition, and the transitions between these three major faunal groups are poorly documented. Late Miocene to Early Pliocene assemblages were more or less static in composition for at least 4 million years (8$4 \mathrm{Ma}$ ) preceding the Plio-Pleistocene transition (3.51.5 Ma) between the Mio-Pliocene and PleistoceneRecent faunas. Plio-Pleistocene assemblages form a continuum that extends between the Mio-Pliocene and Pleistocene-Recent assemblages, indicating that new species were added to pre-existing communities. However, change in more protected environments appears to have lagged behind change in more exposed reef settings. The timing and pattern of species replacement varied from place to place across the Caribbean region.

7. The modern Caribbean species pool is confined to a region that is smaller in area than at any other time in Cenozoic history. Past history suggests that the diversity of a region may not be able to recover fully from losses resulting from ongoing and future environmental perturbations such as those related to anthropogentic disturbance.

Acknowledgements I thank Ken Johnson for help with data analysis. This research was supported by a grant from the US National Science Foundation (EAR-9219138)

\section{References}

Aronson RB, Precht WF (1997) Stasis, biological disturbance, and community structure of a Holocene coral reef. Paleobiology 23:326-346

Bryan JR (1991) A Paleocene coral-algal-sponge reef from southwestern Alabama and the ecology of Early Tertiary reefs. Lethaia 24:423-438

Budd AF, Johnson KG (1996) Recognizing species of Late Cenozoic Scleractinia and their evolutionary patterns. Paleontol Soc Papers 1:59-79

Budd AF, Johnson KG (1997) Coral reef community dynamics over 8 myr of evolutionary time: stasis and turnover. Proc 8th Int Coral Reef Symp 1:423-428

Budd AF, Johnson KG (1999) Origination preceding extinction during late Cenozoic turnover of Caribbean reefs. Paleobiology 25:188-200

Budd AF, Kievman CM (1999) Coral assemblages in Neogene to Recent cores from the Bahamas platform and their use in paleoenvironmental interpretation. SEPM Spec Publ (Concepts in Sedimentary Geology), in press

Budd AF, McNeill DF (1998) Zooxanthellate Scleractinian corals from the Bowden Shell Bed, SE Jamaica. Contrib Tert Quat Geol 35:49-65 
Budd AF, Johnson KG, Edwards JC (1989) Miocene coral assemblages in Anguilla, BWI, and their implications for the interpretation of vertical succession on fossil reefs. Palaios 4:264-275

Budd AF, Stemann TA, Stewart RH (1992) Eocene Caribbean reef corals: a unique fauna from the Gatuncillo Formation of Panama. J Paleontol 66:570-594

Budd AF, Johnson KG, Potts DC (1994a) Recognizing morphospecies of colonial reef corals. I Landmark-based methods. Paleobiology 20:484-505

Budd AF, Stemann TA, Johnson KG (1994b) Stratigraphic distributions of genera and species of Neogene to Recent Caribbean reef corals. J Paleontol 68:951-977

Budd AF, Johnson KG, Edwards JC (1995) Caribbean reef coral diversity during the Early to Middle Miocene: an example from the Anguilla Formation. Coral Reefs 14:109-117

Budd AF, Johnson KG, Stemann TA (1996) Plio-Pleistocene turnover and extinctions in the Caribbean reef coral fauna. In: Jackson JBC, Budd AF, Coates AG (eds), Evolution and environment in tropical America. Univ Chicago Press, Chicago, pp 168-204

Budd AF, Petersen RA, McNeill DF (1998) Stepwise faunal change during evolutionary turnover: a case study from the Neogene of Curaçao, Netherlands Antilles. Palaios 13:167-185

Budd AF, Johnson KG, Stemann TA, Tompkins BH (1999) Pliocene to Pleistocene reef coral assemblages in the Limon Group of Costa Rica. In: Collins LS, Coates AG (eds), The Neogene of the isthmus of Panama: a paleobiotic survey of the Caribbean coast. Bulls Amer Paleontol Spec Vol, in press

Chevalier JP (1977) Aperçu sur la faune corallienne récifale du Néogène. Mémoires du Bureau Recherches Géologiques et Minières 89:359-366

Clark BL, Durham JW (1946) Eocene corals from the Department of Bolivar, Colombia. Geol Soc Am Mem 16:126 pp

Coates AG, Jackson JBC, Collins LS, Cronin TM, Dowsett HJ, Bybell LM, Jung P, Obando JA (1992) Closure of the Isthmus of Panama: the near-shore marine record of Costa Rica and western Panama. Geol Soc Am Bull 104:814-828

Collins LS, Budd AF, Coates AG (1996) Earliest evolution associated with closure of the tropical American seaway. Proc Natl Acad Sci 93:6069-6072

Copper P (1988) Ecological succession in Phanerozoic reef ecosystems: is it real? Palaios 3:136-152

Copper P (1989) Enigmas in Phanerozoic reef development. Mem Ass Australas Palaeontolos 8:371-385

Edinger EN, Risk MJ (1994) Oligocene-Miocene extinction and geographic restriction of Caribbean corals: roles of turbidity, temperature, and nutrients. Palaios 9:576-598

Edinger EN, Risk MJ (1995) Preferential survivorship of brooding corals in a regional extinction. Paleobiology 21:200-219

Evans CC (1986) A field guide to the mixed reefs and siliciclastics of the Neogene Yaque Group, Cibao Valley, Dominican Republic. University of Miami Comparative Sedimentology Laboratory, Rosenstiel School of Marine and Atmospheric Science, Miami, pp 98

Frost SH (1972) Evolution of Cenozoic Caribbean reef faunas. Carib Geol Conf Trans 6:461-464

Frost SH (1977a) Cenozoic reef systems of the Caribbean - prospects for paleoecologic synthesis. In: Frost SH, Weiss MP, Saunders JB (eds), Reefs and related carbonates - ecology and sedimentology. AAPG Studies in Geology 4, Tulsa pp 93-110

Frost SH (1977b) Oligocene reef coral biogeography, Caribbean and western Tethys. Mémoires du Bureau Recherches Géologiques et Minières 89:342-352

Frost SH (1977c) Miocene to Holocene evolution of Caribbean Province reef building corals. Proc 3rd Int Coral Reef Symp 2:353-359

Frost SH (1981) Oligocene reef coral biofacies of the Vicentin, northeast Italy. In: Toomey DF (ed), European fossil reef models. SEPM Special Publication 30, Tulsa, pp 483-540

Frost SH, Langenheim RL (1974) Cenozoic reef biofacies. No Illinois Univ Press, DeKalb, 388 pp
Frost SH, Schafersman SD (1978) Oligocene reef community succession, Damon Mound, Texas. Gulf Coast Geol Soc Trans 28:143-160

Frost SH, Weiss MP (1979) Patch-reef communities and succession in the Oligocene of Antigua, West Indies. Geol Soc Am Bull 90:1094-1141

Frost SH, Harbour JL, Beach DK, Realini MJ, Harris PM (1983) Oligocene reef tract development, southwestern Puerto Rico. Sedimenta IX, University of Miami, Rosenstiel School of Marine and Atmospheric Science, Miami 107 pp

Gauch HG Jr (1982) Multivariate analysis in community ecology. Cambridge University Press, Cambridge, 298 pp

González LA, Ruiz HM, Taggart BE, Budd AF, Monell V (1997) Geology of Isla de Mona, Puerto Rico. In: Vacher HL, Quinn T (eds), Geology and hydrogeology of carbonate islands. Elsevier, Amsterdam, pp 327-358

Goreau TF, Wells JW (1967) The shallow-water Scleractinia of Jamaica: revised list of species and their vertical distribution range. Bull Mar Sci 17:442-453

Gould SJ (1988) Trends as changes in variance: a new slant on progress and directionality in evolution. J Paleontol 62:319-329

Jackson JBC, Budd AF (1996) Evolution and environment: introduction and overview. In: Jackson JBC, Budd AF, Coates AG (eds), Evolution and environment in tropical America. Univ Chicago Press, Chicago, pp 2-10

Jackson JBC, Jung P, Coates AG, Collins LS (1993) Diversity and extinction of tropical American mollusks and emergence of the isthmus of Panama. Science 260:1624-1626

Jackson JBC, Budd AF, Pandolfi JM (1996) The shifting balance of natural communities? In: Erwin D, Jablonski D and Lipps J (eds), Evolutionary paleobiology: essays in honor of James W. Valentine. Univ Chicago Press, Chicago, pp 89-122

Johnson $\mathrm{KG}$ in review. Distinguishing pattern from artifact: modeling the effects of uneven sampling in descriptions of biotic change. Paleobiology

Johnson KG, McCormick T (1998) The quantitative description of biotic change using palaeontological databases. In: Harper DAT (ed) Numerical Palaeobiology, John Wiley, New York, pp 227-247

Johnson KG, Budd AF, Stemann TA (1995) Extinction selectivity and ecology of Neogene Caribbean reef corals. Paleobiology 21:52-73

Kidwell SM, Flessa KW (1995) The quality of the fossil record: populations, species, and communities. Ann Rev Ecol Syst 26:269-299

McCune B, Mefford MJ (1995) PC-ORD, multivariate analysis of ecological data, version 2.0. MJM Software Design, Gleneden Beach, OR

McNeill DF, Budd AF, Borne PF (1997) An earlier (Late Pliocene) first appearance of the reef-building coral Acropora palmata: stratigraphic and evolutionary implications. Geology 25:891-894

Newell ND (1971) An outline history of tropical organic reefs. Am Mus Novit 2465:1-37

Prothero DR (1994) The Late Eocene-Oligocene extinctions. Ann Rev Earth Planetary Sci 22:145-165

Rosen BR (1984) Reef and coral biogeography and climate through the Late Cainozoic: just islands in the sun or a critical pattern of islands? In: Brenchley P (ed) Fossils and climate, John Wiley, New York, pp 201-262

Rosen BR, Turnsek D (1989) Extinction patterns and biogeography of corals across the Cretaceous/Tertiary boundary. Assoc Austral Palaontols Mem 8:355-370

Saunders JB, Jung P, Biju-Duval B (1986) Neogene paleontology in the northern Dominican Republic. Part 1, Field surveys, lithology, environment, and age. Bulls Amer Paleontol 89:1-79

Schuster F (1996) Paleoecology of Paleocene and Eocene corals from Kharga and Farafra oases (Western Desert, Egypt) and the depositional history of the Paleocene Abu Tartur carbonate platform, Kharga Oasis. Tübinger Geowissenschaftliche Arbeiten A 31:96 pp

Sepkoski JJ Jr (1997) Biodiversity: past, present, and future. J Paleontol 71:533-539 
Sheehan PM (1985) Reefs are not so different - they follow the evolutionary pattern of level-bottom communities. Geology 13:46-49

Sheehan PM (1996) A new look at ecologic evolutionary units (EEUs). Palaeogeogr Palaeoclimatol Palaeocol 127:21-32

Stanley SM (1979) Macroevolution. WH Freeman, San Francisco, $332 \mathrm{pp}$

Stanley SM (1986) Anatomy of a regional mass extinction: Plio-Pleistocene decimation of the western Atlantic bivalve fauna. Palaios 1:17-36

Stemann TA (1997) Corals. Tulane Studies in Geology and Paleontology 30(1):31-38

Stemann TA, Bryan JR (1997) Coral survival and community collapse: Paleocene reefs in the Caribbean and Gulf of Mexico. Geol Soc Am Abs Prog 29(6):A404

Vaughan TW (1900) The Eocene and Lower Oligocene coral faunas of the United States with description of a few doubtfully Cretaceous species. US Geol Survey Monograph 39:263 pp

Vaughan TW (1919) Fossil corals from Central America, Cuba, and Porto Rico with an account of the American Tertiary,
Pleistocene, and Recent coral reefs. US Natl Mus Bull 103:189524

Wallace RJ (1969) The paleoecology of the Browns Town and Montpelier Limestones (Oligocene-Miocene) of Jamaica. Unpubl MS thesis, No Illinois Univ, DeKalb IL, 87 pp

Wells JW (1934a) Some fossil corals from the West Indies. Proc US Natl Mus 83:71-110

Wells JW (1934b) Eocene corals from Cuba. Bulls Amer Paleontol 20:147-158

Wells JW (1935) Corals from the Cretaceous and Eocene of Jamaica. Ann Mag Nat Hist (Ser 10) 15:183-194

Wells JW (1945) American old and middle Tertiary larger foraminifera and corals. Part II. West Indian Eocene and Miocene corals. Geol Soc Am Mem 9:25 pp

Wells JW (1956) Scleractinia. In: Moore RC (ed), Treatise on invertebrate paleontology. Geol Soc Am and Univ Kansas Press, Lawrence KS:F328-444

Wells JW, Lang JC (1973) Systematic list of Jamaican shallowwater Scleractinia. Bull Mar Sci 23:55-58 